\title{
DEVELOPING ENGLISH LISTENING MATERIAL FOR THE SEVENTH YEAR STUDENTS OF JUNIOR HIGH SCHOOL
}

\author{
I Gusti Ngurah Agung Wijaya Mahardika \\ English Education Department \\ Institut Hindu Dharma Negeri Denpasar \\ wijayamahardika@ihdn.ac.id
}

\begin{abstract}
The aim of this research is to develop listening materials for teaching listening skill for class 7 of Junior High School based on the School Based Curriculum and the criteria of good listening material. In order to do so, the researcher firstly defines the characteristics of listening materials and activities that should be developed for teaching listening skill for class 7 of junior high school based on the School Based Curriculum and the criteria of good listening material.

The final product of this research is a set of listening material which consist of, 1) 3 Student Books which contain the Listening Material for the students, based on their academic ability. Workbook A contains type A activities for slow students, Workbook B contains type B activities for normal students, and Workbook C contains type $\mathrm{C}$ material for smart students. 2) A Teacher Book which contains the same Listening Material as the students' listening material, completed with Teaching aids and instructions to increase the usability of the material, and the transcript of the Listening Tapes. 3) The last product is the Listening Material in the form of Compact Disc (CD) containing the whole Listening Material and the soft copy of the Listening Transcript.

\section{Introduction}

English mastery is the threshold to further advancement in learning, most prominent books in most subject matters are printed in English, and the world communication depends greatly upon the use of English. Furthermore, English is used in all areas which needed a language that is spoken by everybody in the world, from trade to military purposes. Therefore, mastery

of English is an inevitable requirement for every student and will later prove to be an invaluable skill to help them both in the learning process and real life (Ahmad, 2016).

In Indonesia, English teachers relied heavily on using Student Worksheet (LKS), a kind of student workbook which aimed at giving exercises to the students to work on or a course book. It is a common belief and practice among teachers that the whole learning process rests at the
\end{abstract}


Student Worksheet (LKS) or the course book. In the beginning of the semester teachers simply take one course book which she or he will use and keep on using it. The semester ends when all the materials in the Student Worksheet (LKS) or course book have been taught.

On the other hand, several scholars pointed out that the LKS and Course Books used by teachers in Indonesia are proved to have many factual errors (Collin 2005, as cited by Madya, 2008:9), and worse, the learning activities in them do not help the students to be a good English user because the activities in the course books are not authentic (Wahidah, 2009:5). Furthermore, Suprabawati (2009:4) found that the available Course Books presented materials which are incompatible with the curriculum, in the sense that the course book presented materials which were not in the scope of curriculum and failed to present all the material required by the curriculum. Wahidah (2009:14-38) further states that her study upon three books from three different major publishing companies revealed that the books have several weaknesses namely: 1) The emphasis of the books were to introduce new vocabularies, idioms, meanings, and the usage rules, instead of training the students to use these new vocabularies and idioms and language habit formation. 2) There was a lack of real life usage of the language and also relevant language activities and 3) there was no demand for the students to be able to construct and understand coherent meaning. In short, the books emphasized heavily on the teaching about the language and its rules, instead of teaching the language. This kind of book lead the students to be able to know the language yet failed in truly using the language.

Wahidah (2009:31) further states that the listening activities in the books she studied were very little and the materials used in the listening activities were not authentic. The focus of the aural skill activities (speaking and listening) still focuses on written activities. This is a problem, because Harmer (2007: 5262) stated that there are four skill that must be mastered namely, reading, writing, listening, and speaking, hence every Course Book used by teachers should give equal attention to all these language skills including listening. In Indonesia, the English teaching also places the emphasis on these four skills; however, one of these skills, listening, is largely neglected by students and teachers.

Teachers in Indonesia ten to view listening as an unimportant skill because they think that listening skill is a skill which students will 
eventually pick up and therefore does not need any specific approaches to it. It is also a fact that in the field of English, listening is rarely researched by researchers, thinking that speaking and other skills such as writing and reading are more important skills to master, and needed to be developed intensively (Miller, 2003:1). To add more fuel to the fire of negligence, listening skill is not tested in the National Examination (UAN, Ujian Akhir Nasional) thus giving even more potent excuse for the teachers and students to neglect listening skill. The National Examination for English gives heavy emphasis on Reading and Writing skills. Therefore, teachers and students will pour more effort to deal with speaking and reading tasks.

Despite student's, researchers' and teachers' negligence, listening is a very important skill. It is rather interesting that listening has not received wider attention in the past given that it is the language skill most often used in everyday life. More than forty percent of our daily communication time is spent on listening, thirty-five percent on speaking, sixteen percent on reading, and only nine percent on writing (Burely-Allen 1995 as cited in Miller, 2003:1). Yet, people still consider listening to be an inferior skill to other skills.
Based on the above condition the researcher formulated the nature of materials that should be developed for teaching listening skill for class 7 of junior high school and then based on such knowledge the researcher attempted to develop the material needed for teaching and learning listening for Class 7 of Junior High School.

\section{Theoretical Review}

\subsection{Concept of Materials development}

The first point to be discussed is the nature material, therefore it is important to define the term Materials. Tomlinson (1998) define materials as anything used by teachers or learners to facilitate the learning of a language. Materials could obviously include cassettes, videos, CD-Roms, DVD's, dictionaries, grammar books, readers, workbooks, photocopied exercises, all kinds of realia, lectures and talks by guest speakers, Internet sources, and so on. (Tomlinson, 1998:2).

Materials Development encompasses any kind of activity and/or exercise (games, role plays, readings, problem-solving situations, group discussions, etc.) totally developed from raw texts, with or without pedagogical purposes, for the students' level and created to address a section of the course content, that 
seems to be weak or lack further development or practice.

\section{2 Characteristics of Materials Development}

Within the scope of Materials Development, there are several important features to take into account in the process of creating or adapting teaching materials. Among the many characteristics mentioned by Tomlinson (1998), there are four fundamental of them. The first one is the fact that materials should have an impact on the students and arouse learners' curiosity, attention and interest. By impact Tomlinson refers to materials that make use of different types of sources (TV, newspaper, internet sites, radio, magazines, and letters), have an attractive presentation and appealing content. Obviously, to achieve this, teachers should clearly know his/her students and his/her objectives to develop / adapt an activity for a particular teaching aspect. These materials ought to be relevant, useful and focused on what students are learning at that point.

A second characteristic is exposure to real language which is attained by giving students opportunities to use language in reallife communicative activities. By having guest speakers, radio interviews, class surveys, projects, interviews to other teachers, group discussions, and panels in class students can be exposed to real language. The materials should also stimulate learner's interaction with the input rather than just having passive reception of it. This does not necessarily mean that the learners should always produce language in response to the input, but it does mean that they should always do something mentally or physically in response to it (Tomlinson, 1998).

As a third feature, materials should address different learning styles and intelligences. If teachers know their students, they will design activities in which students can really feel at ease using their learning preferences and abilities. Teachers should develop materials for visual, auditory or tactile students as well as activities for students with bodilykinesthetic, musical, linguistic, logical mathematical, spatial, interpersonal, intrapersonal, and naturalistic intelligences.

The last important feature of Materials Development is the guidance towards students' autonomy and independence. The latest trends in EFL teaching support and encourage the idea that students need to learn to be responsible for their own learning and to know that they can do activities in and out of class by themselves. Giving students' 
choice is a key element in making them autonomous and independent.

\subsection{Teaching Listening}

Nunan (2003) defines listening as an active, purposeful process of making sense of what we hear. In contrary to common belief that listening is a passive skill and it is usually categorized as a receptive skill, listening is actually a very active skill. When someone listens to something, he does not only receive an information but also reacts to the information by relating or contradicting the new information with the existed or prior information. Diaz-Rico (2004) expressed that listening is a meaning construction activity and divided listening into three types based on the purpose. The first is listening to repeat; in which students conduct listening activities to be able to repeat the words listened during the practice, the emphasis of this type of listening on correct pronunciation. An example material for this type of listening is the minimal pair pattern practice; where students are asked to repeat simple phrases that differ by only one phoneme such as "it is a sheep" and "it is a ship". The second type is listening to understand; in this type of listening the aim is to improve and practice students' comprehension. The typical strategy used in this type of listening is by giving a task-based listening where the students are given a listening material and asked to answer to complete a task based on the information given in the listening material. The third type of listening is listening to communicate; this listening activity is aimed to improve students' communicative competence and their ability to communicate fluently and meaningfully. This is done through the integration of all the language skills, and developing the skill of anticipating questions, understanding questions, note taking, as well as pronunciation practices (Diaz-Rico, 2004: 145-154).

\section{4 The Principles of Teaching Listening}

There are some principles that must be taken into account when a teacher wants to teach listening skill, Nunan (2003) proposed the principles as follows:

1) Expose students with different ways of information processing system.

There are two information processing system namely the Bottom Up and the Top Down processing. In Bottom-Up processing the students starts with the components parts of a language such as words, grammar, and the like. On the contrary the Top Down processing starts with student's 
background knowledge either in form of content schema (general information based on previous learning and life experience) or textual schema (awareness of the kinds of information used in a given situation). The best way to help students' learning is by combining these two approaches, through a pre-listening brainstorming. In this process their knowledge of life (the top down process) and their generation of vocabulary and sentences (the bottom up process) will work together, resulting in a more integrated attempt of information processing. Buck 1995 (as cited in Nunan 2003) maintains that the pre-listening activities aimed at two things, which are to provide a context for interpretation and to activate the background knowledge which will help interpretation.

\section{2) Expose Students to Different Type} of Listening.

Exposing students to different types of listening will help them in focusing the attention to the listening materials based on the purpose of the listening. Nunan (2003: 30-31) explained two types of listening the first is the specific listening, where students have to listen to a material and then try to locate a specific information within the text. The second type of listening is the global listening is the type of listening where students try to find out more general information from a material, such as the sequence of events, a main idea and other global information.

\section{3) Teach a Variety of Tasks}

Setting up the task of listening activities can be as challenging as selecting the material. The tasks for listening activities must consider students' condition. Since most of the task is done by the students while listening, it is not supposed to be demanding too much production. For example, a beginner hears a story and asked to write a summary of the story, the task could be difficult simply because the student does not have the ability to write a summary, yet. Tasks that requires too much production cannot be done or cannot be done in real time, and should the student come up with the wrong answer the teacher will be having a hard time trying to know whether the students do not understand the listening or simply fail to express their understanding.

4) Always Consider authenticity and difficulty of the material

When dealing with listening material difficulty, the first aspect to be considered is the speed of speech or rate of speech. Every speaker has different speech rate and decreasing the speech rate of a listening material 
is of course not a solution, because it will hamper the material authenticity. A possible solution is by creating pauses every now and then, either digitally through computer manipulation of the material or manually (by pressing the "pause" button on a tape recorder or other media player). Through this manipulation teacher can use a single material for a range of difficulties by giving appropriate pauses.

\section{Research Method}

This study is categorized as Research and Development. It refers to the evaluating materials in which the findings of the study are used to develop a new product (Gall \& Gall, 2003).

In relation to the above definition, this research can be considered as a preliminary research and development (R\&D) since the aim of this research is to design a new product of listening materials for the first-grade students of Junior High School in Singaraja in terms of their appropriateness towards SchoolBased Curriculum (SBC) and criteria of good listening materials.

Among the scholars in the field of Research and Development, it was Dick \& Carey who developed a model commonly used for Research and Development study. The model by Dick \& Carey can be seen below

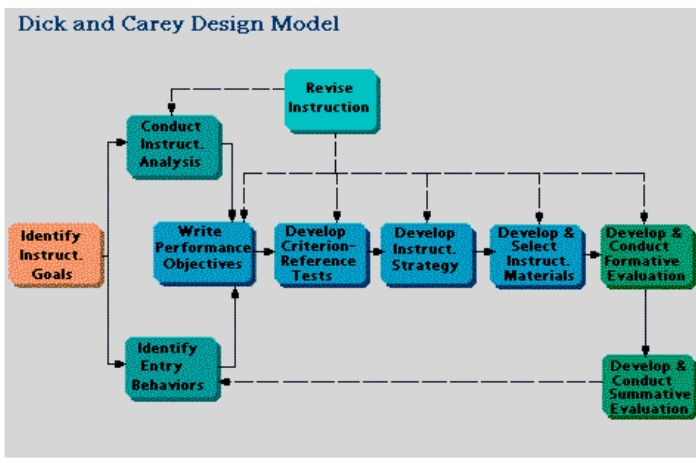

Figure 1

Dick and Carey Design Model

Since this is a preliminary study of $R \& D$ in relation to the designing of Listening materials, the procedure of this research adapted from Dick\& Carey's model of R\&D (2001) in Gall\& Gall (2003). The research design above was simplified in order to make it easier to understand from which it was developed into a new design shown in figure 2 below.

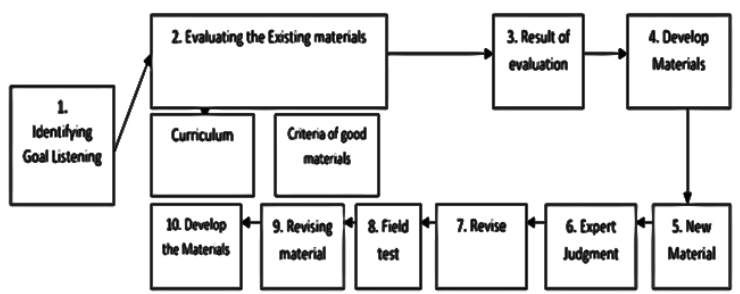

Figure 2

The design adapted from

Dick\& Carey's model of R\&D (2001) in Gall\& Gall (2003) 


\section{Findings and Discussion}

\subsection{The Characteristics of Good}

\section{Listening Material}

The characteristics of good listening material based on the School Based Curriculum are the compatibility of the material with the school-based curriculum, and the orderly presentation of the topics in the material. The material compatibility with the school-based curriculum was judged from the Standard Competency and Basic Competency. The Standard Competency and Basic Competency of the listening material must closely follow the guidelines of the School Based Curriculum. Based on this Standard Competency and Basic Competency, the researcher will develop listening topics which will represent the Standard Competency and Basic Competency required by the School Based Curriculum.

There are four Standard Competencies that must be taught to the students of class VII of Junior High School, two standard competencies in each semester. The followings table shows the Standard Competency and Basic Competency which were taken from the School Based Curriculum for class VII of Junior High School. As for the basic competencies, there were eight basic competencies which must be taught to the students of class VII of Junior High School, with four basic competencies for each semester.

\subsubsection{The Characteristic of Good Listening Material based on the Good Material and Listening teaching and learning Theories}

The characteristic of good listening material based on good listening material are as follows:

1. The materials should have an impact on the students and arouse learners' curiosity, attention and interest, by having an attractive presentation and appealing content. These materials ought to be relevant, useful and focused on what students are learning at that point.

2. The material should give exposure to real language which is attained by giving students opportunities to use language in real-life communicative activities. The materials should also stimulate learner's interaction with the input rather than just having passive reception of it

3. The material should expose students with different ways of information processing system, namely bottom up and top down processing systems. 
5. The material should expose Students to Different Type of Listening. Both the Gist listening and the Specific listening.

6. The material should be developed by considering different levels of the students' academic ability.

The above characteristics were taken from the criteria of good material and the theories on listening teaching and learning. Based on these characteristics the researcher developed the listening material in order to make the material fulfill the criteria of good material and the requirements of listening teaching and learning theories.

\subsection{The Listening topics which are needed to be developed based on the School Based Curriculum}

The researcher developed the topics for the listening materials based on the requirement of the School Based Curriculum, specifically the Standard Competency and Basic Competency of the School Based Curriculum for the seventh year of Junior High School. This was done to ensure the compatibility of the materials developed with the requirement of the School Based Curriculum, and to ensure that the material will be able to fulfill the needs of both teacher and students. The followings are the topics developed by the researcher.

\begin{tabular}{|c|c|c|}
\hline \multicolumn{3}{|c|}{ TOPICS } \\
\hline No & FIRST SE.MIESTER & SECOND SEMIESTFR \\
\hline 1 & Greetings and introduction & Asking and giving services \\
\hline 2 & Command & Asking and giving things \\
\hline 3 & Prohibition & Asking and giving facts \\
\hline 4 & Asking and giving information & Asking and giving opinion \\
\hline 5 & Gratilukde & Like and dislike \\
\hline 6 & apology & Asking for clarification \\
\hline 7 & Instruction & Instruction \\
\hline 8 & List of things & Congratulation/ happy birthday \\
\hline 9 & Congratulation & Announcement \\
\hline 10 & Announcement & Procedural monologue \\
\hline 11 & & Descriptive monologue \\
\hline
\end{tabular}

Table 1. The Listening Topics for first and second semester

The Indonesian National Education System Act No. 20 year 2003 defined curriculum as a set of arrangements and settings about objectives, content, and learning material, and the means which is used as the guidelines of implementing learning activities in achieving certain objectives. (Undang Undang Sistem Pendidikan Nasional: 2003). Since the curriculum is the guidelines of the learning material it is imperative for the material to follow the as closely as possible to the curriculum. Sudiarta (2009) followed suit by stating that material or course book should stands as a whole, which means that the text book or any teaching material should contain the whole or complete teaching material for each unit of competency or sub competency which will be taught. This was where one of the major weaknesses of the English in Focus lies. The English in Focus failed 
to comply with the Curriculum used since it failed to introduce all the topics required by the curriculum.

To avoid the same problem the researcher used the curriculum as main guideline. All the materials developed by the researcher were based on the curriculum, in order to enable students to learn all the material and achieve all the competencies. The result of the field test showed that the material developed by the researcher achieved $88 \%$ level of appropriateness or compatibility with the School Based Curriculum, compared to the English in Focus which only achieved $60 \%$ of compatibility with the curriculum.

\subsection{The Listening Activities which are needed to be developed for the seventh-year student of junior high school}

The activities which are needed to be developed are the activities which fulfill the characteristics of good material and listening teaching and learning theories, namely 1) activities which achieve impact, 2) activities which expose students to real language, 3) activities which expose students with different information processing systems, 4) activities which expose students to different types of listening, and 5) activities with different difficulty levels.
To achieve impact the new material contains colorful pictures which are related to the material being developed. The whole material was printed in full color. This inclusion of pictures is very important because it will prompt students' interest in learning. This is in line the result a research by Keegan (2007) about the importance of visual images in lectures. found that an overwhelming majority $(81 \%)$ of the respondents said they would like lecturers to use more visual images in teaching. The respondents also added that the pictures made the lectures more interesting and increase the concentration level amongst the students (Keegan, 2007).

To expose the students to real language, the listening tapes were recorded using mixture native speakers of English and non-native speaker of English. This was done to familiarize the students from an early stage to the differences in spoken English, such as the dialect of the speaker. It was also based on the consideration that the students, being in Bali, will mostly encounter conversation between non-native speakers with native speakers of English, such as when they meet a guide with foreign guests. Furthermore, the activities in the material were developed were based on daily life activities such as filling an 
identification form or explaining about things they usually do in real life, although still in very simple form, since the target students were the students of the seventh year. The following is the example of the activities in which students use language to express things they do in everyday life.

As stated by Nunan (2003), that listening activities should expose students to both Top Down and Bottom Up information processing system. In order to achieve this the researcher designed the listening material which was divided into three parts, namely the Pre-listening, the Main Listening, and the Post Listening activities. The pre-listening activities were designed to facilitate the mixture of the Top down process and the Bottom Up Process. The new material was completed with the prelistening as a form of improvement from the existing material which left out the pre-listening part form the whole listening material. it should be understood that the students must be prepared for the listening activities. Through the pre-listening activities students are prepared to deal with the listening, as mentioned by several scholars (Nunan 2003; Diaz-Rico, 2004; Miller, 2003; and Harmer, 2007); before listening, students need assistance to activate what they already know about the ideas they are going to hear. Simply being told the topic is not enough. Pre- listening activities are required to establish what is already known about the topic, to build necessary background, and to set purpose for listening. Furthermore, the pre-listening stage also becomes the first activities that the students encounter and usually the easiest ones. It was designed this way in order to attract and maintain students' interest to the listening. Giving easy, simple, and fun activities in the beginning of the class will give the student as sense of security and comfort. In light with this, Nunan (2003) stated that the listening activities should be fun for the students and encourage them to learn and know more.

Nunan (2003: 30-31) explained two types of listening the first is the specific listening, where students have to listen to a material and then try to locate a specific information within the text. The second type of listening is the global listening is the type of listening where students try to find out more general information from a material, such as the sequence of events, a main idea and other global information.

Both of these listening types must be taught to the students, because the students need both of them to be able to comprehend the listening better. The gist listening will 
train them to think globally and train the students to understand and look for the general ideas of a listening conversation or monologue. While on the other hand specific listening train student to look for details and specific information. Gist listening is as important as the specific listening. The new material covered both type of listening.

Lastly, the researcher developed the material with three different difficulty levels, for slow students, normal students, and fast or smart students. Since it is difficult to reorganize the students of a particular class to suit one difficulty level, the researcher opted for another approach. By designing the material to be able to serve three difficulty levels at once, the teacher will have one less problem to cope with. It must be noted that the difficulty level is different for the Main Listening and the Post listening part only, because these are the parts where students will use their listening ability to solve problems. Meanwhile the PreListening part was only an introductory part, brainstorming activities which lead to the Main Listening activities.

\subsection{The Listening Material Development Process}

The research was started with an observation of the classroom activities on English teaching. The researcher found that the teacher gives little emphasis on listening despite the importance of the listening. The teacher stated that the absence of language laboratory and the present material have become problem in teaching listening to the students of seventh year of junior high school. The teacher stated that the material in the existing course book were sometimes different than the ones in the curriculum. The course book was also not interesting for the students since it was not colorful, some of the students expressed their boredom on using the book. Based on the problems found in teaching listening in the junior high school, the researcher then decided to develop listening materials which can be used in the seventh year of junior high school.

The final product is the result of the revision done to solve the problems found during the field testing. The final product is also the improved version of the previously field-tested material, the improvement was based on the criticism from the teacher, experts, and students. The result of the field test showed that he material has very little problems in terms of the content of the material, yet suffer significant flaws in the presentation, and organization. 


\subsection{Conclusion}

The final product of this research is a set of Listening materials in form of three Student Books, one Teacher Book, and a Listening Tape in form of a DVD. The material itself was designed so it will achieve impact on the students, expose the students to real language, with different information processing system, different types of listening, and was developed with three different difficulty levels. The Content of the material closely follows the topics as delineated by the syllabus.

The listening topics which are needed to be developed are the topics which are developed based on the Standard Competency and Basic Competency of the School based Curriculum for the seventh year of junior high school which are divided into two semesters. For the first semester the topics are; greetings and introduction, expressing command, expressing prohibition, asking and giving, expressing gratitude, expressing apology, responding to instruction, responding to list of things, responding to congratulation, responding to announcement, and identifying ideas in announcement. For the second semester the topics are: asking and giving services, asking and giving things, asking and giving facts, asking and giving opinion, like and dislike, asking for clarification, instruction, congratulation/ happy birthday, announcement, procedural monologue, and descriptive monologue.

The activities which are needed to be developed based on the School Based Curriculum for the seventh year of Junior high School and criteria of good listening material are: 1) activities which attract student's attention and to prompt their curiosity towards the learning process, 2) activities which provide chances for the students to study the language not about the language, 3) activities which enable students to utilize both the top down and bottom up processing systems, 4) activities which expose students to different types of listening, and 5) activities which give appropriate tasks for students with different academic ability levels.

In terms of development process, the material was developed based on the weaknesses of the existing material as well as the schoolbased curriculum and the criteria of good listening material. The material was then judged by experts, and the tested in real life situation. The result of the expert judgment and the field test became the basis to further improve and correct the material into the final version, thus became the final product of this study. In terms of the outlook of the materials, the final product should be developed by 
using colors and pictures to make the material more interesting. The paper size should also be considered to create and distinguishing effect for the final product, thus enabling students to differentiate the final product with other course books.

\subsection{Suggestion}

This research is a preliminary research aiming at developing listening material for students of Class VII of Junior High School. Further test still needs to be done to this particular material. Teachers and other researchers are encouraged to develop their own material for different level of students and also different focus of language learning, such as reading, speaking, and writing. Further material development as mentioned before should involve more scholars and experts from different disciplines to make the developed material becomes a better material for both the students and the teachers. A number of ideas have not been covered in this research such as the combination of listening with Information Technology. Due to the rapid development of technology, teachers and researcher must always try to keep up with the recent development and developing materials which may utilize the novelty of technology to create even more interesting and meaningful material and activities.
This task would mean cooperation not only with experts in the field of language learning but also with experts from computer technology field. 


\section{REFERENCES}

Ahmad S. R. 2016. Importance of English communication skills. International Journal of Applied Research. Vol. 2(3). pp. 478-480 (2016).

Diaz-Rico, L, T. 2004. Strategies for Teaching English Learners. USA. Pearson.

Gall \& Gall. 2003. Educational Research. New Jersey: Pearson Education, inc

Harmer, Jeremy. 2007. How to Teach English. Malaysia. Longman

Keegan, Sobhana Nair. 2007. The Importance of Visual Images in Lectures: case study on tourism management student. http://www.heacademy.ac.uk Lassets/hlst/documents/johlst e/vol6no1/60147.pdf.

Madya, Suwarsih. 2008. "Curriculum Innovations in Indonesia and Strategies to Implement Them". In Yeon Hee Choi and Bernard Splosky (ed) ELT Curriculum Innovation and Implementation in Asia. (page 1-40). Seoul. eduKLC.

Miller, Lindsay. 2003. Developing Listening Skill with Authentic Materials.

www.elithillside.com/article4 doc.

Nunan, David. 2003. Practical English Language Teaching. New York:
The

McGraw-Hill

Companies, inc.

Suprabawati, Yuni. 2009. The analysis of Course Book LINKED TO THE WORLD 1 Used by the First Year Students of Senior High Schools in Singaraja in the Academic Year of 2008/2009. (Unpublished Thesis). Singaraja. Undiksha Singaraja.

Tomlinson, Brian. 1998. Materials Development in Language Teaching. U. K: Cambridge University Press.

Wahidah, Siti, "Panduan Pendidik", Paper. 2009 